\title{
Herbage Production Following Tree and Shrub Removal in the Pinyon-Juniper Type of
} Arizona

\author{
WARREN P. CLARY AND DONALD A. JAMESON
}

\begin{abstract}
Herbage production was evaluated after overstory removal from different sites within the pinyon-juniper type. Average annual production varied from 43 to $643 \mathrm{~kg} / \mathrm{ha}$ before treatment and 715 to $3,703 \mathrm{~kg} / \mathrm{ha}$ after treatment. Production variation among sites was related to annual precipitation, pretreatment tree canopy, pretreatment nitrate-nitrogen, and presence or absence of limestone soils. Grasses increased in the composition from 46 to $73 \%$ on the average, while forbs decreased from 21 to $19 \%$, and half-shrubs and shrubs decreased from 33 to $8 \%$.
\end{abstract}

The pinyon-juniper vegetation type covers a substantial portion of western and southwestern United States. Recent estimates range from 17.3 million (Forest-Range Task Force 1972) to 32.5 million ha (West et al. 1975), with 3.4 million (Forest-Range Task Force 1972) to 5.7 million ha (Ffolliott and Thorud 1975) in Arizona. The extent of this vegetation type makes it important even though the per-hectare productivity is relatively low.

The diversity of products available from pinyon-juniper woodlands, which gives it some of its appeal, has also resulted in conflicts of use (Gifford and Busby 1975; Aldon and Loring 1977). Many have suggested that the best use is as range for grazing animals (Springfield 1976). As a result, substantial areas of pinyon and juniper trees have been removed to reduce forage plant competition.

Better productivity information is needed so research and management attention can be focused to obtain the best yield of all products and amenities from this vegetation type. The objective of this study was to determine the herbage production after overstory removal from various sites within the pinyon-juniper type of Arizona. Sites with soils developed from different parent rocks were evaluated for their ability to produce native herbaceous vegetation.

\section{Description}

\section{Climate}

The climate throughout the pinyon-juniper type is rather severe for tree growth, characterized by low precipitation, low relative humidity, hot summers, and much clear weather and intense sunshine. Average annual rainfall in the Arizona pinyon-juniper type varies from 30 to $50 \mathrm{~cm}$ while typical January and July mean temperatures are $2^{\circ}$ and $22^{\circ} \mathrm{C}$, respectively.

In Arizona, a prominent and unique climatic feature is the presence of two distinct precipitation periods. This biomodal pattern is most distinct in the Flagstaff/Prescott area (Jameson 1969). Precipitation generally comes from the Pacific Ocean during the winter and from the Gulf of Mexico during the summer. Topo-

Authors are principal range scientist, U.S. Dep. Agr. Forest Service, Shrub Sciences Laboratory, Intermountain Forest and Range Experiment Station. Provo, Utah 84601 , and professor of range science, College of Forestry and Natural Resources, Colorado State University, Fort Collins $\mathbf{8 0 5 2 3}$, respectively. Data for this study were collected while authors were with the Rocky Mountain Forest and Range Experiment Station, U.S. Dep. Agr. Forest Service.

Manuscript received June 17, 1979.

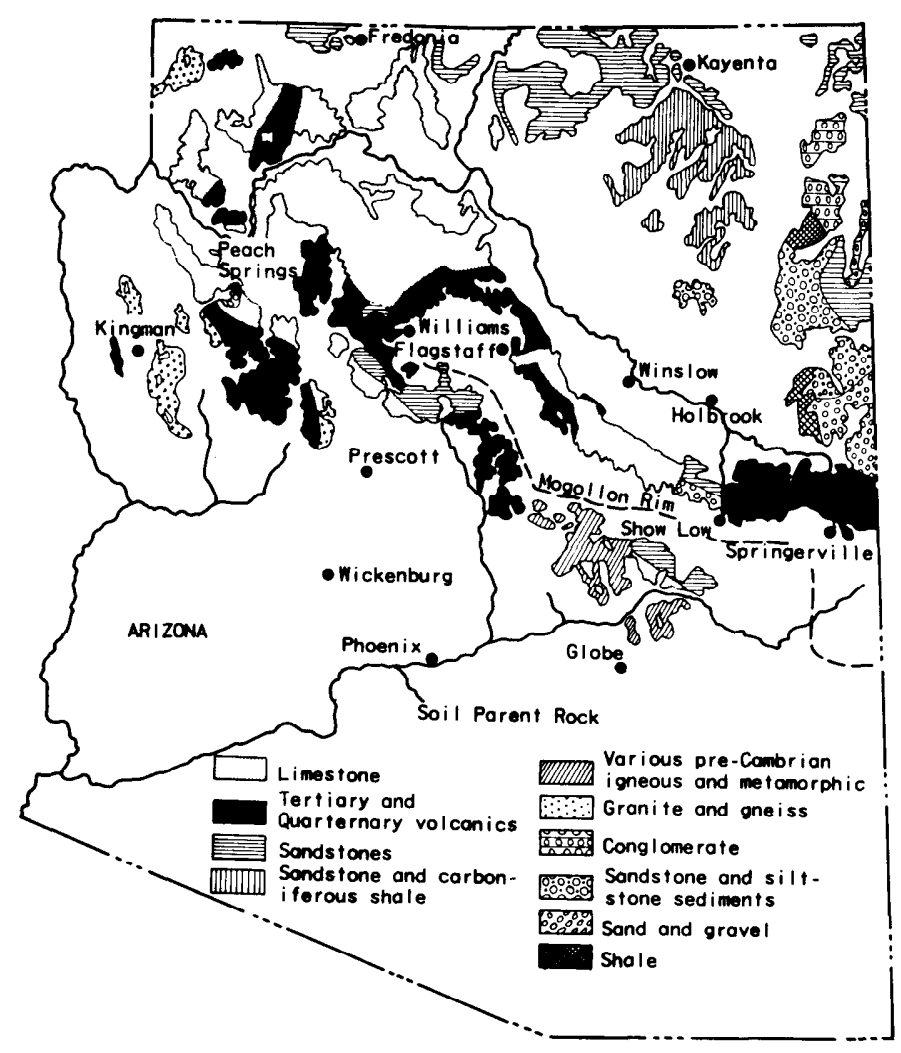

Fig. 1. Simplified geologic map of the pinyon-juniper type in Arizona.

graphy and typical storm paths combine to produce variations in precipitation. Central Arizona receives the most precipitation since it experiences the full effect of both summer and winter storms, whereas northern and western Arizona is summer dry, and east-central Arizona is winter dry.

\section{Soils}

The parent rocks of soils supporting pinyon-juniper vary widely from basalt, limestone, sandstone, and granitc to mixed alluvium (Fig. 1). Soil surface textures vary from stony, cobbly, and gravelly sandy loams to clay and clay loam. About one-third of Arizona pinyon-juniper grows on soils formed from basalt. Most of this is in the Springerville and Thunderbird soil series (Jameson and Dodd 1969). The next largest area is underlain by Kaibab and Redwall limestones. The sandstones are also a major group of parent rocks.

Information developed by the U.S. Dept. Agr. Soil Conservation Service ${ }^{1}$ suggests that herbage production is expected to be

\footnotetext{
'Soil Conservation Service. Technical range site descriptions. Phoenix, Arizona.
} Memo. 
less on limestone than on basalt soils, especially on shallow soils.

\section{Vegetation}

The pinyon-juniper type constitutes the largest "forest" type in Arizona (Shupe 1965). This type is commonly referred to as a woodland rather than a forest because the trees are generally too small for sawtimber. Although the physiognomy appears rather monotonous, consisting of a rather open forest of low, roundcrowned trees, there are variations of both tree overstory and the predominant understory species. The most consistent tree species is pinyon (Pinus edulis); however, one or several juniper species usually dominate the stand. Typical juniper-understory combinations are one-seed juniper (Juniperus monosperma) with blue grama (Bouteloua gracilis) in the dry winter areas north of the Mogollon Rim; Utah juniper (J. osteosperma) with big sagebrush (Artemisia tridentata) in the areas with cold, moist winters in the most northerly portion of the State; and alligator juniper ( $J$. deppeana) at higher elevations and Utah juniper at lower elevations, with chaparral [mainly shrubby oaks (Quercus spp.) and manzanita (Arctostaphylos spp.)] south of the Mogollon Rim where winters are cool and moist.

\section{Study Areas}

This study was conducted on a 22 0.4-ha plots distributed from northwest of Peach Springs in western Arizona to Show Low in the east-central portion of the State. The plots were located in pairsone on each side of a tertiary or quaternary basalt flow boundary. This provided an opportunity to compare herbage production across the State on soils developed from basalt flows versus soils developed from nonbasaltic geologic formations (Table 1).

Criteria used to select the locations were:

1. Soils appeared to be typical for the geologic formation.

2. Slopes were less than $10 \%$.

3. Plot pairs were within a single range unit (had a similar grazing history).

4. The two members of the pair were within $0.8 \mathrm{~km}$ of each other.

\section{Methods}

\section{Treatment}

The overstory of pinyon-juniper trees was killed mostly by girdling, although sawing was necessary in some cases. The dead trees remained on the plots, thus soil disturbance was minimal. Stumps of alligator juniper were sprayed with polychlorobenzoic acid ${ }^{2}$ in diesel oil to prevent sprouting (Jameson and Johnsen 1964). Shrub live oak (Quercus turbinella) was treated with fenuron in $25 \%$ pellets. Other shrubs were treated with polychlorobenzoic acid. Herbaceous forbs and half-shrubs on all plots were treated with 2,4-D butoxy ethanol ester (Johnsen 1962). Followup spot treatments of a similar nature were made for two years. The plots were fenced to exclude livestock, but not wildlife, following the initial treatments.

\section{Measurements}

Within each 0.4-ha plot, 50 subplots were randomly located. These were the basis for most study measurements. Tree and shrub overstory canopy was determined before treatment with a spherical densiometer (Lemmon 1956). Rock, litter, and herbaceous basal cover were measured with a point frame using 50 points spaced $1 \times 2 \mathrm{dm}$ within a $1 \times 1 \mathrm{~m}$ frame

Standing crop measurements of vegetation (considered to be a measure of annual herbage production for all understory plants except perennial succulents) were made every other year near the end of the growing season. Green weight estimates were made by trained observers on $500.9-\mathrm{m}^{2}$ subplots per plot. One of every five plots was chosen at random to be clipped and oven-dried to provide a ratio conversion for herbage data to a dry-weight basis.

Complete soil profile descriptions ${ }^{3}$ were made according to standard soil survey techniques on each plot (Soil Survey Staff

${ }^{2}$ This paper reports research involving pesticides. It does not contain recommendations for their use, nor does it imply that uses discussed here have been registered. All use of pesticides must be registered by appropriate state and federal agencies before they can be recommended.

${ }^{3}$ Soil profile descriptions were made by G. Wendt and M.L. Miller, U.S. Dep. Agr Soil Conservation Service, and T. Anderson and W.R. Mitchell, U.S. Dep. Agr. Forest Service. Revision of nomenclature by D.R. Taylor, U.S. Dep. Agr. Soil Conservation Service.

Table 1. Plot locations and selected characteristics.

\begin{tabular}{|c|c|c|c|c|c|c|}
\hline Location name & County & Parent rock & Soil series & $\begin{array}{c}\text { Annual } \\
\text { precipitation } \\
\text { (cm) }\end{array}$ & $\begin{array}{c}\text { Tree canopy } \\
\text { cover } \\
(\%)\end{array}$ & $\begin{array}{c}\text { Nitrate- } \\
\text { nitrogen } \\
(\mathrm{kg} / \mathrm{ha})\end{array}$ \\
\hline Babbitt Lake & Coconino & $\begin{array}{l}\text { Kaibab limestone } \\
\text { Basalt }\end{array}$ & $\begin{array}{l}\text { Tortugas gravelly loam } \\
\text { Thunderbird stony loam }\end{array}$ & $\begin{array}{l}31.8 \\
31.8\end{array}$ & $\begin{array}{l}31 \\
29\end{array}$ & $\begin{array}{l}9 \\
1\end{array}$ \\
\hline Double A & Coconino & $\begin{array}{l}\text { Mixed alluvium } \\
\text { Basalt }\end{array}$ & $\begin{array}{l}\text { Disterheff gravelly loam } \\
\text { Springerville cobbly clay }\end{array}$ & $\begin{array}{l}46.0 \\
46.0\end{array}$ & $\begin{array}{l}22 \\
23\end{array}$ & $\begin{array}{l}1 \\
3\end{array}$ \\
\hline Black Canyon & Mohave & $\begin{array}{l}\text { Redwall limestone } \\
\text { Basalt, cinders, and ash }\end{array}$ & $\begin{array}{l}\text { Tortugas stony and rocky loam } \\
\text { Springerville stony silty clay }\end{array}$ & $\begin{array}{l}39.1 \\
39.1\end{array}$ & $\begin{array}{l}12 \\
17\end{array}$ & $\begin{array}{r}1 \\
13\end{array}$ \\
\hline Yampai & Yavapai & $\begin{array}{l}\text { Supai sandstone } \\
\text { Basalt }\end{array}$ & $\begin{array}{l}\text { Dye loam } \\
\text { Springerville stony clay }\end{array}$ & $\begin{array}{l}37.1 \\
37.1\end{array}$ & $\begin{array}{r}10 \\
9\end{array}$ & $\begin{array}{l}3 \\
9\end{array}$ \\
\hline Indian Mountain & Yavapai & $\begin{array}{l}\text { Granitc alluvium } \\
\text { Basalt and cinders }\end{array}$ & $\begin{array}{l}\text { Lynx gravelly loam } \\
\text { Springerville very stony clay }\end{array}$ & $\begin{array}{l}44.2 \\
44.2\end{array}$ & $\begin{array}{l}18 \\
19\end{array}$ & $\begin{array}{r}31 \\
1\end{array}$ \\
\hline Hell Canyon & Yavapai & $\begin{array}{l}\text { Redwall limestone } \\
\text { Basalt }\end{array}$ & $\begin{array}{l}\text { Winona stony gravelly loam } \\
\text { Thunderbird stony silty clay }\end{array}$ & $\begin{array}{l}34.5 \\
34.5\end{array}$ & $\begin{array}{l}5 \\
0\end{array}$ & $\begin{array}{l}1 \\
9\end{array}$ \\
\hline Witty Tom & Yavapai & $\begin{array}{l}\text { Quartzite alluvium } \\
\text { Basalt }\end{array}$ & $\begin{array}{l}\text { Cross stony, silty, clay loam } \\
\text { Springerville stony clay }\end{array}$ & $\begin{array}{l}39.1 \\
39.1\end{array}$ & $\begin{array}{r}9 \\
19\end{array}$ & $\begin{array}{l}9 \\
1\end{array}$ \\
\hline Rimrock & Yavapai & $\begin{array}{l}\text { Verde Lake limestone } \\
\text { Basalt and cinders }\end{array}$ & $\begin{array}{l}\text { Retriever loam } \\
\text { Thunderbird stony clay loam }\end{array}$ & $\begin{array}{l}31.8 \\
31.8\end{array}$ & $\begin{array}{r}13 \\
2\end{array}$ & $\begin{array}{r}1 \\
22\end{array}$ \\
\hline Sand Rock Draw & YYavapai & $\begin{array}{l}\text { Kaibab limestone } \\
\text { Basalt }\end{array}$ & $\begin{array}{l}\text { Hogg loam } \\
\text { Thunderbird cobbly clay loam }\end{array}$ & $\begin{array}{l}56.6 \\
56.6\end{array}$ & $\begin{array}{r}29 \\
7\end{array}$ & $\begin{array}{l}1 \\
1\end{array}$ \\
\hline Buckhead Mesa & Gila & $\begin{array}{l}\text { Mazatzal quartzite } \\
\text { Basalt }\end{array}$ & $\begin{array}{l}\text { Daze cobbly sandy loam } \\
\text { Springerville very stony clay }\end{array}$ & $\begin{array}{l}56.4 \\
56.4\end{array}$ & $\begin{array}{l}43 \\
23\end{array}$ & $\begin{array}{l}1 \\
1\end{array}$ \\
\hline Lone Pine & Navajo & $\begin{array}{l}\text { Tertiary outwash } \\
\text { Basalt }\end{array}$ & $\begin{array}{l}\text { Showlow gravelly loam } \\
\text { Thunderbird clay }\end{array}$ & $\begin{array}{l}37.1 \\
37.1\end{array}$ & $\begin{array}{l}13 \\
16\end{array}$ & $\begin{array}{l}3 \\
1\end{array}$ \\
\hline
\end{tabular}




\begin{tabular}{|c|c|c|c|c|}
\hline \multirow[b]{3}{*}{ Location } & \multicolumn{4}{|c|}{ Parent rock } \\
\hline & \multicolumn{2}{|c|}{ Basalt } & \multicolumn{2}{|c|}{ Nonbasalt } \\
\hline & Average & Range & Average & Range \\
\hline Babbitt Lake & 1551 & $1213-1834$ & 971 & $858-1096$ \\
\hline Double A & 1426 & $827-2094$ & 979 & $771-1221$ \\
\hline Black Canyon & 1503 & $1088-2207$ & 1184 & $796-1546$ \\
\hline Yampai & 1077 & $839-1318$ & 1148 & $1020-1316$ \\
\hline Indian Mountain & 1165 & $692-2083$ & 3224 & $1220-4651$ \\
\hline Hell Canyon & 1090 & $643-1443$ & 840 & $703-1003$ \\
\hline Witty Tom & 1804 & $1100-2378$ & 1770 & $1096-2109$ \\
\hline Rim Rock & 715 & $692-735$ & 869 & 536-1091 \\
\hline Sand Rock Draw & 1731 & $1273-2595$ & 1371 & $1150-1551$ \\
\hline Buckhead Mesa & 1809 & $1488-2207$ & 3703 & $3352-4221$ \\
\hline Lone Pine & 993 & $638-1455$ & 771 & $559-1020$ \\
\hline Average & 1351 & & 1530 & \\
\hline
\end{tabular}

1951). Soil samples were collected from each horizon, and mechanical analyses were made in the laboratory by the Bouyoucos hydrometer method.

Soil samples were collected from the surface $25 \mathrm{~cm}$ of each soil profile and analyzed for nutrient content with LaMotte ${ }^{4}$ soil test kits.

A precipitation storage gage was established at each plot pair, and readings were taken at least twice yearly. Gages were charged with oil and ethylene glycol in the winter and oil only in the summer. The average season distribution of precipitation at each study site was estimated based upon records of nearby U.S. National Weather Service Stations (Sellers and Hill 1974). Selection of comparison stations was made on the basis of proximity and similarity to the study areas in elevation, physiography, vegetation, and average annual precipitation - in most cases two adjacent stations were used.

\section{Analysis}

The analysis of herbage production (grasses, forbs, and shrubby plants) was based on an average of the fourth, sixth, and eighth post-treatment years in order to avoid the initial disturbance of treatment. The data were subjected to multiple regression analysis to determine if certain site characteristics could be used to estimate post-treatment herbage production. Several initial regression screenings were conducted to investigate correlations of herbage production with various topographic, climatic, soil, and plant characteristics of the site. Comparison among soils groups were made using $t$-tests.

\section{Results and Discussion}

\section{Herbage Production}

Average herbage production after overstory removal varied from 715 to $3,703 \mathrm{~kg}$ / ha with the highest production occurring on a quartzite and on a granite soil (Table 2). The production before treatment ranged from 43 to $643 \mathrm{~kg} / \mathrm{ha}$. Production values compared across all sites showed no significant difference between basalt and nonbasalt means.

The variables most effective for prediction of post-treatment production were annual precipitation, antecedent or pretreatment tree canopy cover, antecedent or pretreatment nitrate-nitrogen, and presence or absence of limestone soils. The effects of these variables were consistent when combined with the different variables tested, and there were logical cause-effect reasons for their use.

Average annual precipitation was used as a predictor since differences in seasonal distribution had no detectable effect on herbage production. Pretreatment tree canopy cover apparently was an effective predictor because, under stable conditions, those sites which support the most tree cover are usually the most productive (Lanner 1975; Springfield 1976). Pretreatment nitrate-

\footnotetext{
${ }^{4}$ Mention of trade name does not constitute endorsement by the U.S. Department of Agriculture.
}

nitrogen appears to be a useful indicator of site fertility, particularly on those sites with little tree canopy cover. Climax plant communities seem to inhibit nitrification (Rice and Pancholy 1972, 1973; Lodhi 1978) and there is evidence of such effect in the pinyon-juniper woodland (O'Rourke and Ogden 1969). Apparently, the a mount of nitrate tends to be low in the presence of a tree cover, but varies in the absence of tree cover reflecting productivity of the site. Thus, the amount of nitrate-nitrogen present helps differentiatc among those which have a low tree canopy cover because of low productivity and those which have a low tree canopy cover because of historical events such a disturbance by cutting or fire.

Tree canopy cover did not appear to be an effective predictor of herbage production on limestone soils. Reduced herbage production on limestone-derived soils in comparison to most other soils in this study is evidently a reflection of a worldwide phenomenon (Whittaker and Niering 1968); therefore, a joint variable (tree canopy cover $X$ presence or absence of limestone soils) was included in the analysis.

The equation recommended for estimating post-treatment herbage yield is:

$$
\begin{gathered}
Y=42.1 X_{1}+45.2 X_{2}+46.4 X_{3}-32.7 X_{4}-1174 \\
\text { where: } \quad Y=\text { average annual herbage production in } \mathrm{kg} / \mathrm{ha} \\
X_{1}=\text { average annual precipitation in } \mathrm{cm} \\
X_{2}=\text { pretreatment canopy cover in percent } \\
X_{3}=\text { pretreatment nitrate- } \mathrm{N} \text { in } \mathrm{kg} / \mathrm{ha} \\
X_{4}=\text { canopy cover } \mathrm{x} \text { presence }(1) \text { or absence }(0) \text { of } \\
\text { limestone soil } \\
R^{2}=0.77 \\
S_{\mathrm{s} . \mathrm{x}}=429
\end{gathered}
$$

Of the above variables, nitrate-N data are probably most apt to be lacking for any particular area. The following equation can be used if no nitrate- $\mathrm{N}$ data are available:

$$
\begin{aligned}
& Y=33.0 X_{1}+38.8 X_{2}-33.5 X_{4}-405 \\
& R^{2}=0.58 \\
& S_{\text {y.x }}=556
\end{aligned}
$$

These equations were developed from a data set with the following ranges in independent variables: precipitation $31.8-56.6 \mathrm{~cm}$; nitrate- $\mathrm{N} 1-31 \mathrm{~kg} / \mathrm{ha}$; and canopy cover $0-43 \%$.

Production levels measured in this study exceeded those generally reported under grazed conditions (Arnold et al. 1964; Aro 1971; Clary 1971) although some reports include only those plants deemed as "forage." Reduced herbage production on grazed range compared to ungrazed range is common in the West (Pase and Thilenius 1968; Reynolds and Martin 1968; Smith 1967). Therefore, caution should be used in projecting the actual levels of production obtained in fenced plots to that expected under grazed conditions.

\section{Botanical Composition}

The proportion of grasses by weight in the post-treatment com- 
Table 3. Average annual production for grasses, forbs, half-shrubs, and shrubs; and live biomass for perennial succulents.

Annual production $(\mathrm{kg} / \mathrm{ha})$

Pre- Post-

treatment $^{1}$ treatment ${ }^{1}$

Grasses

Three-awn (Aristida spp.)

Side-oats grama (Bouteloua curtipendula)

Black grama ( $B$. eriopoda)

Blue grama ( $B$. gracilis)

Hairy grama (B. hirsuta)

Tobosa (Hilaria mutica)

Bullgrass (Muhlenbergia emersleyi)

Ricegrass (Oryzopsis hymenoides and O. micrantha

Vine-mesquite (Panicum obtusum)

Bluegrass (Poa fendleriana and

P. longiligula)

Bottlebrush squirreltail (Sitanion hystrix)

Sand dropseed (Sporobolus cryptandrus)

Others

Total

$\begin{array}{rr}1 & 35 \\ 5 & 155 \\ 2 & 22 \\ 31 & 350 \\ 6 & 69 \\ 30 & 62 \\ \mathrm{~T}^{2} & 69 \\ 1 & 18 \\ & \\ 1 & 31 \\ 1 & 28 \\ & \\ 1 & 84 \\ 1 & 31 \\ 20 & 97\end{array}$

$100 \pm 17 \quad 1051 \pm 139$

Forbs

Eriogonum (Eriogonum spp.)

Spurge (Euphorbia spp.)

Common sunflower (Helianthus annuus)

Toadflax penstemon (Penstemon linarioides)

Russian thistle (Salsola kali)

Flannel mullein (Verbascum thapsus)

Annual goldeneye (Viguiera annua)

Others

Total

Half-shrubs and shrubs

Rubber rabbitbrush (Chrysothamnus nauseosus)

Wright eriogonum (Eriogonum wrightii)

Broom snakeweed (Gutierrezia sarothrae)

Mimosa (Mimosa spp.)

Others

Total

Grand Total

$216 \pm 30 \quad 1440 \pm 158$

Perennial succulents

Utah agave (Agave utahensis)

Prickly-pear (Opuntia spp.)

Blue yucca (Yucca baccata)

Others

Total

\begin{tabular}{rr}
\multicolumn{2}{c}{ Biomass (kg/ha) } \\
\hline 130 & 0 \\
242 & 0 \\
5 & 0 \\
1 & 0
\end{tabular}

IPretreatment data-l year

Post-treatment data- 3 years

$2 \mathrm{~T}=$ less than $1 / 2 \%$ of production

position increased significantly to $73 \%$ from a pretreatment average of $46 \%$ (excluding perennial succulents) (Table 3). The most prominent species was blue grama with about $24 \%$ of the posttreatment production. Interestingly, blue grama, which has a reputation of low productivity and had not been expected to respond greatly to pinyon-juniper removal (Jameson 1970), increased approximately 11 times, while tobosa, a seemingly more vigorous species, only doubled.

The proportion of forbs decreased slightly from 21 to $19 \%$, but the tall annual forbs were much more evident after treatment. Half-shrubs and shrubs dropped significantly from 33 to $8 \%$ of the composition even though the most abundant nongrass species after treatment was broom snakeweed.

The substantial live biomass of perennial succulents was elimi- nated by the herbicides (Table 3 ).

The treatment applied (removal of trees, application of herbicides, and protection from livestock grazing) was designed to allow maximum increase of native grass species. The treatment was successful in increasing both the quantity of grasses produced and, generally, the proportion of grasses in the composition. However, the post-treatment proportion of grasses, although averaging $73 \%$, ranged from 40 to $92 \%$. This proportion was not predictable from current site information. For example, the post-treatment proportion of grasses was not related to the site characteristics used to predict herbage production, nor was it related to soil parent rock or pretreatment composition. General observation suggests that a part of the differences in composition response may result from particular species-soils interactions, but further research is needed to determine this. The only difference in composition among plots which appeared to be consistent was a lesser proportion of shrubby plants on limestone soils (significant at 0.05 level).

\section{Conclusions}

Considerable variation exists in herbage production potential of the pinyon-juniper woodland. Therefore, if the intent is to manage portions of the woodland for maximum herbage yield, careful consideration should be given to site selection to obtain the best return for input of labor and energy (Clary et al. 1974). The highest herbage yields in this study were obtained from sites with high annual precipitation, high pretreatment tree canopy or nitrate values, and nonlimestone soils. In Arizona, these conditions are most common just south of the Mogollon Rim. Since costs of converting from pinyon-juniper to grass increase with tree canopy coverage (Jameson 1971), cost efficiency may suggest treatment of sites with high nitrogen values ahead of sites with high tree canopy percent.

Average production after tree removal, herbicide application, and protection from grazing increased from the pretreatment values by the following proportions: grasses, 10-1/2 times; forbs, 6 times; shrubby plants, 1-2/3 times; and total herbage, 6-2/3 times.

Suggested further investigations include (1) the apparently high productivity of granite and quartzite soils, and (2) the seemingly slow response of tobosa after overstory removal.

\section{Literature Cited}

Aldon, E.F., and T.J. Loring (tech. coord.). 1977. Ecology, uses, and management of pinyon-juniper woodlands: Proceedings of the workshop. U.S. Dep. Agr. Forest Serv. Gen. Tech. Rep. RM-39, 48 p. Rocky Mt. Forest and Range Exp. Sta., Fort Collins, Colo.

Arnold, J.F., D.A. Jameson, and E.H. Reid. 1964. The pinyon-juniper type of Arizona: Effects of grazing, fire, and tree control. U.S. Dep. Agr. Prod. Res. Rep. 84, 28 p.

Aro, R.S. 1971. Evaluation of pinyon-juniper conversion to grassland. J. Range Manage. 24:188-197.

Clary, W.P. 1971. Effects of Utah juniper removal on herbage yields from Springerville soils. J. Range Manage. 24:373-378.

Clary, W.P., M.B. Baker, Jr., P.F. O'Connell, T.N. Johnsen, Jr., and R.E. Campbell. 1974. Effects of pinyon-juniper removal on natural resource products and uses in Arizona. U.S. Dep. Agr. Forest Serv. Res. Pap. RM-128, 28 p. Rocky Mt. Forest and Range Exp. Sta., Fort Collins, Colo.

Ffolliott, P.F., and D.B. Thorud. 1975. Water yield improvement by vegetation management: Focus on Arizona. Report No. UA/SR NR75101. Nat. Tech. Inform. Serv., U.S. Dep. Comm., Springfield, Va.

Forest-Range Task Force. 1972. The nation's range resources-a forestrange environmental study. U.S. Dep. Agr. Forest Serv., Forest Resour. Rep. 19, 147 p. Washington, D.C.

Gifford, G.F., and F.E. Busby (ed.). 1975. The pinyon-juniper ecosystem: A symposium. 194 p. Utah State Univ., Logan. [May 1975.]

Jameson, D.A. 1969. Rainfall patterns on vegetation zones in northern Arizona. Plateau 41:105-111.

Jameson, D.A. 1970. Juniper root competition reduces basal area of blue grama. J. Range Manage. 23:217-218.

Jameson, D.A. 1971. Optimum stand selection for juniper control on southwestern woodland ranges. J. Range Manage. 24:94-99. 
Jameson, D.A., and J.D. Dodd. 1969. Herbage production differs with soil in the pinyon-juniper type of Arizona. U.S. Dep. Agr. Forest Serv. Res. Note RM-131, 4 p. Rocky Mt. Forest and Range Exp. Sta., Fort Collins, Colo.

Jameson, D.A., and T.N. Johnsen, Jr. 1964. Ecology and control of alligator juniper. Weeds. 12:140-142.

Johnsen, T.N., Jr. 1962. Chemical control of Colorado rubberweed in Arizona. Weeds 10:328-329.

Lanner, R.M. 1975. Pinyon pines and juniper of the southwestern woodlands. p. 1-17. In: The pinyon-juniper ecosystem: A symposium. $194 \mathrm{p}$. Utah State Univ., Logan [May 1975.]

Lemmon, P.E. 1956. A spherical densiometer for estimating forest overstory density. Forest. Sci. 2:314-320.

Lodhi, M.A.K. 1978. Comparative inhibition of nitrifiers and nitrification in a forest community as a result of the allelopathic nature of various tree species. Amer. J. Bot. 65:1135-1137.

O'Rourke, J.T., and P.R. Ogden. 1969. Vegetative response following pinyon-juniper control in Arizona. J. Range Manage. 22:416-418.

Pase, C.P., and J.F. Thilenius. 1968. Composition, production, and site factors of some grasslands in the Black Hills of South Dakota. U.S. Dep. Agr. Forest Res. Note RM-103, 8 p. Rocky Mt. Forest and Range Exp. Sta., Fort Collins, Co.

Reynolds, H.G., and S.C. Martin. 1968. Managing grass-shrub cattle ranges in the Southwest. U.S. Dep. Agr., Agr. Handb. 162, 44 p. (Rev.)
Rice, E.L., and S.K. Pancholy. 1972. Inhibition of nitrification by climax ecosystems. Amer. J. Bot. 59:1033-1040.

Rice, E.L., and S.K. Pancholy. 1973. Inhibition of nitrification by climax ecosystems. II. Additional evidence and possible role of tannins. Amer. J. Bot. 60: 691-702.

Sellers, W.D., and R.H. Hill (eds.) 1974. Arizona climate 1931-1972. Univ. of Ariz. Press, Tucson. 616 p.

Shupe, D.G. 1965. Arizona's forest area and timber volume. U.S. Dep. Agr. Forest Serv. Res. Note INT-33, 4 p. Intermountain Forest and Range Exp. Sta., Ogden, Utah.

Smith, D.R. 1967. Effects of cattle grazing on a ponderosa pine-bunchgrass range in Colorado. U.S. Dep. Agr. Tech. Bull. 1371, 60 p.

Soil Survey Staff. 1951. Soil survey manual. U.S. Dep. Agr. Handb. 18, 503 p. [as supplemented May 1960.]

Springfield, H.W. 1976. Characteristics and management of southwestern pinyon-juniper ranges: The status of our knowledge. U.S. Dep. Agr. Forest Serv. Res. Pap. RM-160, 32 p. Rocky Mt. Forest and Range Exp. Sta., Fort Collins, Colo.

West, N.E., K.H. Rea, and R.J. Tausch. 1975. Basic synecological relationships in juniper-pinyon woodlands. p. 41-53. In: The pinyon-juniper ecosystem: A symposium. 194 p. Utah State Univ., Logan. [May 1975.]

Whittaker, R.H., and W.A. Niering. 1968. Vegetation of the Santa Catalina Mountains, Arizona. IV. Limestone and acid soils. J. Ecol. 56:523-544. 